\title{
Utilization of Kura Clover-Reed Canarygrass Silage Versus Alfalfa Silage by Lactating Dairy Cows ${ }^{1}$
}

\author{
K. L. Kammes, ${ }^{*}$ G. B. H. Heemink, ${ }^{*}$ K. A. Albrecht, $†$ and D. K. Combs ${ }^{\star 2}$ \\ *Department of Dairy Science, and \\ †Department of Agronomy, University of Wisconsin, Madison 53706
}

\begin{abstract}
The mixture of kura clover (Trifolium ambiguum M. Bieb.) and reed canarygrass (Phalaris arundinacea L.) has proven to be extremely persistent in the northern United States, but information about dairy cow performance on this mixture is lacking. Twenty lactating Holstein cows were used in a crossover design to compare dry matter $(\mathrm{DM})$ intake and milk production from diets containing kura clover-reed canarygrass silage (KRS) or alfalfa (Medicago sativa L.) silage (AS). Forages were cut, wilted, ensiled in horizontal plastic bags, and allowed to ferment for at least $50 \mathrm{~d}$ before beginning the feeding experiment. The KRS was approximately $40 \%$ kura clover and $60 \%$ reed canarygrass. Treatments were total mixed rations formulated with either 57\% of total DM from 1) AS or 2) KRS. Experimental periods were $28 \mathrm{~d}$, with the first $14 \mathrm{~d}$ for diet adaptation and the last $14 \mathrm{~d}$ for measurement of intake and milk production. The neutral detergent fiber (NDF) concentrations of AS and KRS were 37.3 and $47.3 \%$, respectively. The fermentation analyses indicated that both silages underwent a restricted fermentation, producing primarily lactic acid and some acetic acid. Dry matter intake ( $24.2 \mathrm{vs} .22 .8 \mathrm{~kg})$ and $4 \%$ fat-corrected milk (32.8 vs. $30.9 \mathrm{~kg}$ ) were significantly higher for cows fed AS than for cows fed KRS. Cows consumed less NDF (6.7 vs. $8.0 \mathrm{~kg}$ ) and less digestible NDF (3.0 vs. $4.4 \mathrm{~kg}$ ) when fed AS diets compared with KRS diets, but the pool of ruminally undegraded NDF was similar $(3.7 \mathrm{~kg})$ between diets. Cows produced $1.5 \mathrm{~kg}$ of milk/kg of DM consumed regardless of the diet, indicating that digestible NDF of KRS was utilized with similar efficiency as the cell wall constituents of AS, but the intake of cows fed KRS may have been limited by rumen fill. Milk fat concentration tended to be higher for cows fed AS, but

\footnotetext{
Received November 14, 2007.

Accepted April 6, 2008.

${ }^{1}$ This research was supported by funding through a series of USDA-
} Cooperative State Research, Education, and Extension Service (CSREES) special grants.

${ }^{2}$ Corresponding author: dkcombs@wisc.edu
\end{abstract}

the milk true protein concentration and yields of fat and protein did not differ by treatment. Milk urea nitrogen content was higher when cows consumed AS (16.4 mg/ dL) compared with KRS $(13.4 \mathrm{mg} / \mathrm{dL})$. The cows fed KRS consumed more NDF but less total DMI, based on the results from this trial with diets formulated to contain approximately $60 \%$ of DM as forage, resulting in slightly lower milk yields than cows fed excellentquality AS. This grass-legume mixture has the potential to be a source of quality forage for dairy cows in regions where alfalfa persistence is a problem.

Key words: forage utilization, pasture, silage, milk production

\section{INTRODUCTION}

Forages are a key component of dairy rations in confinement and grazing operations. Fields and pastures used to produce forages for dairy cows should contain persistent forage species, produce large amounts of high-quality forage throughout the growing season, and result in high milk production per cow and per hectare of land.

Alfalfa (Medicago sativa L.) is the predominant forage legume grown and fed to lactating dairy cows in the midwestern United States because it has the highest yield potential and feeding value of the perennial forage legumes. However, alfalfa is not suitable for all soil conditions, especially soils that are poorly drained or that have low $\mathrm{pH}$, and is vulnerable to winter-kill. In addition, alfalfa is not commonly used in grazing systems because cattle are at risk of bloat and the stands decline because of damage caused by grazing animals. Cool-season grasses and legumes tend to be the highest producing species in the Upper Midwest and are often planted together in pastures for dairy cattle. These mixtures offer the benefits of increased yield, improved seasonal distribution of forage, and higher nutritive quality when compared with grass monocultures. Combining legumes with grasses also reduces dependence on nitrogen fertilizer. Grass-legume mixtures reduce the possibility of bloat, decrease the risk of winter-kill, and provide greater stand longevity 
when compared with pure legume stands. (Zemenchik et al., 2002).

Kura clover (Trifolium ambiguum M. Bieb.) and reed canarygrass (Phalaris arundinacea L.) grown together result in a mixture that is persistent and high yielding, with the potential to be a quality forage source for lactating dairy cows. Both species are cool-season perennial forages with an extensive rhizome system, which contributes to their persistence and grazing tolerance (Brummer and Moore, 2000). The quality of kura clover is higher than that of most other forage legumes, including alfalfa (Allinson et al., 1985; Sheaffer and Marten, 1991; Sleugh et al., 2000). Reed canarygrass produces high yields of total biomass (Marten and Hovin, 1980) and has the potential to produce more summer regrowth (Balasko and Nelson, 2003), resulting in greater seasonal distribution. The mixture of reed canarygrass and kura clover produces similar biomass yields as alfalfa (K. A. Albrecht, unpublished data). In contrast to its reputation as a low-quality forage, the release of newer varieties of reed canarygrass containing low levels of alkaloids offers potential for improved animal performance, and these varieties have similar or greater nutrient digestibilities when compared with other perennial cool-season grasses (Buxton and Marten, 1989; Buxton, 1990).

This mixture, grown in permanent pastures, requires careful management. The greatest production occurs in May and June, similar to other cool-season forage crops in the midwestern environment, resulting in surplus forage in the spring. Failure to properly manage this flush of spring growth will result in overmature, lowquality forage that is not suitable for grazing or hay production. Some pastures can be taken out of the grazing system during the spring flush to mechanically harvest high-quality forage as hay or silage to be used during times when growth is not abundant.

Besides being used in grazing systems, this mixture could also be used in confinement systems where environments are not consistent for alfalfa production. Kura clover and reed canarygrass are able to tolerate drought, wet soils and short-term flooding, soils with low $\mathrm{pH}$, cold open winters, and ice sheeting (Pederson, 1995; Carlson et al., 1996). Because of their winter hardiness, adaptation to diverse soil and climatic conditions, and performance under conditions that are less than optimal for alfalfa, this mixture may provide an alternative forage in environments not suitable for alfalfa.

Research has been performed in laboratories with small-scale silos or bags to evaluate silage characteristics of these forages after undergoing fermentation. Results indicated ensiled kura clover was well preserved, with minimal changes in forage quality (Seguin and
Mustafa, 2003; Contreras-Govea et al., 2006). The $\mathrm{pH}$ and VFA profile of ensiled reed canarygrass suggest proper fermentation occurred (Cherney et al., 2006), and mixtures of kura clover and reed canarygrass also fermented well in laboratory silos (K. A. Albrecht, unpublished data). However, the intake and lactation performance of dairy cows fed this mixture as fermented silage are not known.

The objective of this trial was to compare DMI and performance of lactating dairy cows fed a TMR containing equal DM from either alfalfa silage (AS) or kura clover-reed canarygrass silage (KRS) as the sole source of forage in the diet.

\section{MATERIALS AND METHODS}

\section{Forage Harvest}

The primary growth of a mixture of approximately $40 \%$ 'Endura' kura clover in the bud stage and $60 \%$ 'Palaton' (low-alkaloid) reed canarygrass in the stemelongation stage was harvested on June 7, 2005, from fields established in spring 1999. The second cutting of 'Magnum V' alfalfa was harvested on June 30 in the early bud stage, $31 \mathrm{~d}$ after a first harvest was made from fields that were established in spring 2003. Both the mixture and alfalfa fields were harvested as silage 4 times the previous year. Soil phosphorus and potassium levels were maintained at the optimum to high range, based on soil tests and extension recommendations. No nitrogen fertilizer was applied to the kura clover-reed canarygrass mixture, which had been grazed intermittently in subsequent years. Forages were cut by using a conventional mower conditioner, field wilted to 35 to $40 \% \mathrm{DM}$, chopped with a pull-type forage harvester to a theoretical length of $2.9 \mathrm{~cm}$, and ensiled without additives in separate horizontal plastic bags (Up North Plastics Inc., Cottage Grove, MN).

\section{Animals and Diets}

Twenty multiparous lactating Holstein cows were used in a crossover design with 2 experimental periods of $28 \mathrm{~d}$ each. The first $14 \mathrm{~d}$ of each period was allowed for adaptation to the diet. At the beginning of the study, cows averaged $190 \pm 16$ (mean \pm SD) DIM, $33.2 \pm 5.5$ $\mathrm{kg} / \mathrm{d}$ of milk, and $667 \pm 81 \mathrm{~kg}$ of BW. Cows were housed at the University of Wisconsin-Madison Arlington Agricultural Research Station in individual tie stalls or stanchions and had free-choice access to water throughout the trial. Cows were milked twice daily in a milking parlor and turned outside in a concrete lot for $3 \mathrm{~h}$ daily after the morning milking, with access to water but no feed. The Animal Care Committee of the College of Agricultural and Life Sciences of the University of Wis- 
consin-Madison approved all procedures involving animals.

The study was conducted from July 29 to September 25,2005 . Treatments were TMR formulated with either $57 \%$ of total DM from 1) AS or 2) KRS. The TMR consisted of silage, ground high-moisture corn, and supplement containing soybean meal (48\% CP), corn gluten meal, minerals, and vitamins. Both diets had the same feed ingredients except for the forage, which the sole source was either AS or KRS, and chemical composition of the diets was mathematically calculated from individual feedstuffs. The TMR was mixed once daily and fed ad libitum twice daily with 67 and $33 \%$ of TMR offered at 1000 and $1700 \mathrm{~h}$, respectively. The amount of feed offered was adjusted daily to obtain approximately 5 to $10 \%$ orts. Dry matter $\left(48 \mathrm{~h}\right.$ at $\left.60^{\circ} \mathrm{C}\right)$ of forages was determined weekly, and diets were adjusted to account for changes in DM content to maintain a constant forage-to-concentrate ratio.

\section{Sampling and Analysis}

Samples of AS and KRS were collected weekly during feed-out throughout the trial and stored at $-20^{\circ} \mathrm{C}$ pending analysis. Forage samples were composited by period and analyzed by Dairyland Laboratories Inc. (Arcadia, WI) for nutrient composition and fermentation profile by using AOAC (2006) methods for DM (method 930.15), ash (method 942.15), CP (method 954.01), and ammonia-nitrogen (method 920.03). Lignin, NDF, and $\mathrm{ADF}$ were determined by using methods described by Goering and Van Soest (1970). Organic acids and ethanol were measured by using a modification of the HPLC method of Siegfried et al. (1984). Neutral detergent fiber digestibility was determined by a 48 -h in vitro procedure (Goering and Van Soest, 1970) at the University of Wisconsin Soil and Forage Analysis Laboratory (Marshfield, WI).

Dry matter intake and milk production were recorded daily throughout the experiment; however, only d 15 through 28 of each period were used in analysis. Efficiency of conversion of feed DM was computed for each cow by dividing mean milk yield by mean DMI for d 15 through 28 of each period. Milk samples were collected at 4 consecutive milkings from d 25 (p.m.) through 27 (a.m.) of each period and analyzed for fat, protein, lactose, SNF, and MUN by the AgSource Milk Analysis Laboratory (Menomonie, WI) with a Foss FT6000 nearinfrared analyzer (Foss Electric, Hillerød, Denmark).

Ort samples were collected once daily before the morning feeding on d 24 through 28 of each period. Orts were dried at $60^{\circ} \mathrm{C}$ for $48 \mathrm{~h}$, composited by cow and period, ground to pass through a 1-mm screen (Wiley mill, Arthur H. Thomas, Philadelphia, PA), and ana- lyzed for DM, CP, NDF, ADF, and ash. The analytical $\mathrm{DM}$ was determined by oven-drying at $100^{\circ} \mathrm{C}$ for $24 \mathrm{~h}$, and ash content was determined by ashing at $550^{\circ} \mathrm{C}$ for $12 \mathrm{~h}$. Samples were analyzed for CP (method 2001.11; AOAC, 2006) with the following modifications: $0.3 \mathrm{~g}$ of sample was analyzed; $15 \mathrm{~mL}$ of $\mathrm{H}_{2} \mathrm{SO}_{4}, 2.87 \mathrm{~g}$ of $\mathrm{Na}_{2} \mathrm{SO}_{4}$, and $0.13 \mathrm{~g}$ of $\mathrm{CuSO}_{4}$ were added to each tube for digestion; digestion time was $90 \mathrm{~min} ; 40 \mathrm{~mL}$ of water was added to the tubes after digestion; samples underwent steam distillation into a boric acid solution (4\% wt/ vol) containing $0.20 \%$ methyl red indicator solution and $0.98 \%$ bromocresol green solution; and $0.1 \mathrm{~N} \mathrm{H}_{2} \mathrm{SO}_{4}$ was used to titrate the distillate. Ash-corrected NDF was determined according to Van Soest et al. (1991) adapted for an Ankom ${ }^{200}$ Fiber Analyzer (Ankom Technology, Fairport, NY) by using $\alpha$-amylase and sodium sulfite, and $\mathrm{ADF}$ was determined as described by Goering and Van Soest (1970) adapted for an Ankom ${ }^{200}$ Fiber Analyzer (Ankom Technology).

Apparent total tract nutrient digestibilities were measured by using lanthanum as an external marker. A gelatin capsule (Torpac Inc., Fairfield, NJ) containing $\mathrm{La}_{2} \mathrm{O}_{3}$ dissolved in $\mathrm{HCl}$ and carried on wheat middlings was administered twice daily at 0700 and $1900 \mathrm{~h}$ orally via a balling gun on d 18 through 28 to provide approximately $0.87 \mathrm{~g}$ of lanthanum/d. Fecal grab samples were collected twice daily at 0700 and $1900 \mathrm{~h}$ on $\mathrm{d} 24$ through 28 of each period. Fecal samples were composited by cow and period, freeze-dried (period 1) or oven-dried at $60^{\circ} \mathrm{C}$ (period 2) to a constant weight, ground to pass through a 1-mm Wiley mill screen, and analyzed for $\mathrm{DM}, \mathrm{CP}, \mathrm{NDF}, \mathrm{ADF}$, and ash as described previously. Duplicate 1-g fecal samples were weighed into $30-\mathrm{mL}$ beakers and ashed in a muffle furnace (Thermolyne 62700, Barnstead/Thermolyne Corp., Dubuque, IA) at $500^{\circ} \mathrm{C}$ for $16 \mathrm{~h}$. After ashing, $15 \mathrm{~mL}$ of $\mathrm{HCl}$ was added to each beaker and allowed to stand for $1 \mathrm{~h}$. Beaker contents were then diluted to $50 \mathrm{~g}$ in a standard 100$\mathrm{mL}$ class A volumetric flask with deionized water. The fecal concentration of lanthanum was measured by inductively coupled plasma-optical emission spectroscopy (Vista-MPX Simultaneous ICP-OES, Varian, Palo Alto, CA) at Analab Inc. (Fulton, IL) by using wavelengths $333.749,379.082,379.477,399.852$, and $408.671 \mathrm{~nm}$ to produce a median value. Total tract nutrient digestibilities were calculated from lanthanum and nutrient concentrations in orts-adjusted diet and feces.

Data were statistically analyzed by using the MIXED procedure of SAS (SAS Institute, 1999) with the following model:

$$
\mathrm{Y}_{\mathrm{ijk}}=\mu+\mathrm{T}_{\mathrm{i}}+\mathrm{P}_{\mathrm{j}}+\mathrm{C}_{\mathrm{k}}+\mathrm{E}_{\mathrm{ijk}},
$$

where $\mu$ is the overall mean, $T_{i}$ is the fixed effect of treatment ( $i=1$ to 2 ), $P_{j}$ is the fixed effect of period ( $j=$ 
Table 1. Nutrient composition and fermentation profile of silages

\begin{tabular}{lcc}
\hline Variable & $\begin{array}{c}\text { Alfalfa } \\
\text { silage }\end{array}$ & $\begin{array}{c}\text { Kura clover-reed } \\
\text { canarygrass silage }\end{array}$ \\
\hline DM, \% & 36.3 & 42.9 \\
CP, \% of DM & 22.0 & 16.1 \\
ADF, \% of DM & 32.6 & 34.0 \\
NDF, \% of DM & 37.4 & 47.3 \\
NDFD, \% of NDF & 44.5 & 64.9 \\
Lignin, \% of DM & 6.6 & 3.9 \\
Ash, \% of DM & 13.2 & 9.1 \\
NFC, \% of DM & 24.0 & 23.1 \\
pH & 4.5 & 4.4 \\
Lactic acid, \% of DM & 4.1 & 3.4 \\
Acetic acid, \% of DM & 1.9 & 0.7 \\
Propionic acid, \% of DM & $<0.01$ & $<0.01$ \\
Butyric acid, \% of DM & $<0.01$ & $<0.01$ \\
Iso-butyric acid, \% of DM & $<0.01$ & $<0.01$ \\
Ethanol, \% of DM & $<0.01$ & $<0.01$ \\
Ammonia-nitrogen, \% of CP & 23.1 & 18.0 \\
Total fermentation acids & 6.0 & 4.1 \\
Lactate:acetate ratio & $2.2: 1$ & $5.0: 1$ \\
Lactate, \% of total acids & 68.2 & 83.2 \\
\hline
\end{tabular}

${ }^{1} \mathrm{NDFD}=\mathrm{NDF}$ digestibility, determined from in vitro fermentation for $48 \mathrm{~h}$.

${ }^{2} \mathrm{NFC}=100-(\mathrm{NDF}+\mathrm{CP}+$ ether extract + ash $)$.

1 to 2$), C_{k}$ is the random effect of cow ( $k=1$ to 20$)$, and $\mathrm{E}_{\mathrm{ijk}}$ is the residual error term, assumed to be normally distributed.

During the second period, one cow was removed from the trial because of an injury. Consequently, data from 20 and 19 cows were analyzed for periods 1 and 2 , respectively. Significance was declared at $P \leq 0.05$ and a trend was declared at $P \leq 0.10$.

\section{RESULTS AND DISCUSSION}

\section{Forages and Diets}

The nutrient compositions of AS and KRS presented in Table 1 are means from composite samples for periods 1 and 2. As expected, greater concentrations of lignin and lower concentrations of NDF and NDF digestibility were observed in the pure legume (AS) compared with the legume-grass mixture (KRS). Although NDF was 10 percentage units higher in KRS than in AS, $\mathrm{ADF}$ concentration was similar between the 2 silages. Kura-reed silage contained more hemicellulose (NDF $\mathrm{ADF}$ ), resulting in higher NDF digestibility. Limited information on KRS is available; the composition of KRS in this study is consistent with mixtures of fermented kura clover and reed canarygrass at similar proportions in other studies. In other research, the composition of KRS silage ranged from 15.6 to $24.6 \% \mathrm{CP}$, 23.8 to $32.0 \% \mathrm{ADF}, 38.1$ to $54.9 \% \mathrm{NDF}$, and 51.6 to $67.6 \%$ NDF digestibility as mixtures matured over a 4wk period, (K. A. Albrecht, unpublished data).
The fermentation profiles (Table 1) show that both silages underwent a restricted fermentation, producing mainly lactic acid and some acetic acid, and had a similar $\mathrm{pH}$. The fermentation characteristics of these silages were similar to the target levels suggested by Kung and Shaver (2001) for legume and mixed-legume silages. With the exception of lower lactic acid, they are also comparable to the results obtained in other research (K. A. Albrecht, unpublished data) with AS. Alfalfa silage had greater concentrations of lactic acid, acetic acid, and total fermentation acids than KRS, but KRS had a higher lactate-to-acetate ratio and a greater percentage of the total fermentation acids as lactate than AS. Alfalfa would be expected to have higher buffering capacity than KRS, and consequently more acid would be required for AS to reach the same $\mathrm{pH}$ as KRS. The $\mathrm{pH}$ was similar for both silages; therefore, greater acid production in the AS would be expected and was observed. The greater concentration of acetate in AS may be due to lower concentrations of soluble sugars in AS, and lactic acid bacteria could metabolize lactate to produce acetate if substrate was limiting (Lindgren et al., 1990). Both silages had less than $0.01 \%$ propionic, butyric, and iso-butyric acids and ethanol, indicating they did not undergo clostridial fermentation or excessive metabolism by yeasts.

According to Albrecht and Muck (1991), legumes often undergo extensive protein degradation during ensiling. This is consistent with the high concentrations of ammonia present in the 2 silages, suggesting extensive protein breakdown. Alfalfa silage had a higher concentration of ammonia-nitrogen than KRS. The extent of proteolysis is dependent on the rate of $\mathrm{pH}$ drop during ensiling (McKersie, 1985). Because the final $\mathrm{pH}$ was similar for both silages, the rate of decline for AS was likely slower than that for KRS, resulting in greater protein hydrolysis in AS. The high buffering capacity, low levels of water-soluble sugars, and lower DM content of AS could also contribute to a greater protein breakdown in AS than in KRS.

The ingredients and nutrient composition of the diets are listed in Table 2 . The diets contained approximately a 57:43 forage-to-concentrate ratio on a DM basis. Differences in forage composition were reflected in the mean nutrient composition of both treatment diets. Both diets met or exceeded the nutrient requirements for mid- to late-lactation dairy cows producing approximately $35 \mathrm{~kg}$ of milk/d (NRC, 2001).

\section{Cow Performance}

Intake and apparent total tract digestibilities are presented in Table 3. Dry matter intake of cows on the AS diet was $1.4 \mathrm{~kg} / \mathrm{d}$ higher $(P<0.01)$ than that of cows 
Table 2. Ingredient and nutrient composition of dietary treatments

\begin{tabular}{lcc}
\hline & \multicolumn{2}{c}{ Treatment $^{1}$} \\
\cline { 2 - 3 } Composition & AS diet & KRS diet \\
\hline & $-\%$ of dietary DM - \\
Ingredient & 57.1 & - \\
Alfalfa silage & - & 57.1 \\
Kura clover-reed canarygrass silage & 32.1 & 32.1 \\
Ground high-moisture corn & 10.8 & 10.8 \\
Protein-mineral supplement & \\
Nutrient & & \\
CP & 20.4 & 17.0 \\
NDF & 25.6 & 33.1 \\
ADF & 20.0 & 20.8 \\
Ash & 10.4 & 8.0 \\
\hline
\end{tabular}

${ }^{1}$ Treatment: AS = alfalfa silage KRS = kura clover-reed canarygrass silage.

${ }^{2}$ Supplement contained: $37.17 \%$ soybean meal (48\% CP), $45.42 \%$ corn gluten meal, $4.44 \%$ calcium carbonate, $1.94 \%$ dicalcium phosphate, $0.83 \%$ magnesium oxide, $6.58 \%$ salt, and $3.62 \%$ vitamin $\mathrm{A}, \mathrm{D}$, E premix, on a DM basis.

on the KRS diet. Intake paralleled the differences observed in the nutrient composition of forages and treatment diets, with cows fed AS consuming $1.3 \mathrm{~kg}$ more $\mathrm{CP}(P<0.01), 1.3 \mathrm{~kg}$ less NDF $(P<0.01)$, and $0.3 \mathrm{~kg}$ more $\operatorname{ADF}(P<0.05)$ compared with cows fed KRS. There were no significant differences in DM and OM digestibilities between the AS and KRS diets; however, the apparent digestibility of AS diet was greater $(P<$ 0.01 ) for CP, by 5.2 percentage units, and lower for $\mathrm{NDF}(P<0.01)$ and ADF $(P<0.01)$, by 9.0 and 7.2 percentage units, respectively, than that of the KRS diet.

Differences in physical and chemical attributes of legumes and grasses likely contributed to the lower DMI for cows fed KRS than those fed AS. Characteris-

Table 3. Comparison of the effects of alfalfa silage (AS) and kura clover-reed canarygrass silage (KRS) on intake and apparent total tract digestibility

\begin{tabular}{lrrrr}
\hline & \multicolumn{2}{c}{ Treatment $^{1}$} & & \\
\cline { 2 - 3 } Item & AS diet & KRS diet & SEM & $P<$ \\
\hline Intake, kg/d & & & & \\
DM & 24.2 & 22.8 & 0.7 & 0.01 \\
OM & 23.0 & 21.4 & 0.7 & 0.05 \\
CP & 5.3 & 4.0 & 0.2 & 0.01 \\
NDF & 6.7 & 8.0 & 0.3 & 0.01 \\
ADF & 5.2 & 4.9 & 0.2 & 0.05 \\
Apparent digestibility, \% & & & & \\
DM & 63.1 & 63.0 & 1.2 & NS \\
OM & 65.4 & 65.1 & 1.2 & NS \\
CP & 66.1 & 60.9 & 1.1 & 0.01 \\
NDF & 45.2 & 54.2 & 2.1 & 0.01 \\
ADF & 45.1 & 52.3 & 2.1 & 0.01 \\
\hline
\end{tabular}

${ }^{1}$ Treatment: $\mathrm{AS}=$ alfalfa silage KRS = kura clover-reed canarygrass silage. tics of different forages, including fiber quantity and digestibility, in addition to rates of degradation and passage, may help explain the intake results. Because grass contains more NDF with greater digestibility than that of legumes, cows consumed more NDF and more digestible NDF when fed the KRS diet than when fed the AS diet. Although grass fiber has greater digestibility than legumes, grasses generally have a slower digestion rate than legumes (Smith et al., 1972). Inherently low rates of fermentation of grass silage mean that high digestibility of grass requires longer periods of fermentation in the rumen.

Particle breakdown and size distribution in the rumen are also different for grasses and legumes. Dewhurst et al. (2003) noted that cows consuming alfalfa had a low proportion of large particles $(>2 \mathrm{~mm})$ and a high proportion of intermediate particles $(0.106$ to 2 $\mathrm{mm}$ ) compared with grass-fed cows. The rapid breakdown of alfalfa in the rumen results in small particles with a greater surface area, allowing for faster digestion and increased passage rates. Grass particles, which are elongated and slender, usually pass from the rumen more slowly than the cuboidal fragments of legumes (Buxton et al., 1996). The longer residence time of filamentous grass particles in the rumen may be due to entrapment in the longer fiber mat and increased buoyancy associated with a higher amount of potentially digestible NDF in cows fed grass.

These characteristics and the positive relationship between NDF and rumen fill suggest that the DMI of cows fed KRS was restricted by rumen fill. Mertens (1987) indicated that cows consume approximately $1.2 \%$ of their BW/d as NDF when intake is limited by rumen capacity. This is the level of NDF $(8.03 \mathrm{~kg}$ of $\mathrm{NDF} / 667 \mathrm{~kg}$ of $\mathrm{BW} \times 100=1.2 \%$ ) consumed by cows fed KRS, but the cows fed AS consumed only $1.0 \%$ of their BW as NDF in this trial.

Although intake of total NDF and digestible NDF were higher for the cows consuming KRS, the amount of ruminally undegraded NDF was similar $(3.7 \mathrm{~kg})$ between treatments. A higher intake of NDF and a similar intake of indigestible NDF between diets would be expected if intake were limited by the presence of indigestible fiber in the rumen (Dado and Allen, 1996). On the basis of these observations, it is also possible that intake was restricted by undegraded NDF present within the rumen for both groups.

The intake of cows fed the KRS diet was probably limited by the time required to digest fiber, reduce particle size, and move undigested residues through the digestive tract. This is consistent with the findings of Dewhurst et al. (2003), who reported that cows fed grass silage had lower voluntary intakes, higher rumen fills, and slower rumen outflow rates than cows fed AS. 
Table 4. Comparison of the effects of alfalfa silage (AS) and kura clover-reed canarygrass silage (KRS) diets on milk yield and milk composition

\begin{tabular}{lcccc}
\hline & \multicolumn{2}{c}{ Treatment $^{1}$} & & \\
\cline { 2 - 3 } Item & AS diet & KRS diet & SEM & $P<$ \\
\hline Production, kg/d & & & & \\
$\quad$ Milk yield & 34.6 & 33.4 & 0.96 & 0.09 \\
4\% FCM & 32.8 & 30.9 & 1.03 & 0.05 \\
Fat & 1.29 & 1.16 & 0.05 & NS \\
Protein & 1.12 & 1.04 & 0.03 & NS \\
Lactose & 1.70 & 1.58 & 0.05 & 0.01 \\
SNF & 3.14 & 2.91 & 0.08 & 0.01 \\
FE, ${ }^{2}$ kg of milk/kg of DMI & 1.45 & 1.48 & 0.05 & NS \\
Milk composition, \% & & & & \\
Fat & 3.67 & 3.53 & 0.12 & 0.09 \\
Protein & 3.18 & 3.16 & 0.06 & NS \\
Lactose & 4.82 & 4.79 & 0.04 & NS \\
SNF & 8.91 & 8.85 & 0.07 & NS \\
Milk urea, mg of N/dL & 16.4 & 13.4 & 0.34 & 0.01 \\
\hline
\end{tabular}

${ }^{1}$ Treatment: $\mathrm{AS}=$ alfalfa silage KRS = kura clover-reed canarygrass silage.

${ }^{2} \mathrm{FE}$ = feed efficiency, computed on a per-cow basis as the mean kilograms of daily milk produced divided by the mean kilograms of daily DMI.

Milk yield and composition are listed in Table 4 . The higher milk $(P<0.09)$ and FCM $(P<0.05)$ yields for AS are likely a result of the increased DMI for cows consuming the AS diet. Feed efficiency was similar for both forages, with approximately $1.5 \mathrm{~kg}$ of milk produced per kilogram of DM consumed, which suggests that digestible NDF of KRS was utilized as efficiently for milk production as were the cell wall constituents of AS. Yields of fat and protein were not affected by treatment, but lactose $(P<0.01)$ and SNF $(P=0.01)$ yields were higher for cows fed AS. Milk fat percentage tended to be higher $(P=0.09)$ for cows fed the AS diet. The concentrations of lactose and SNF were similar for the 2 groups, indicating that the observed increase in lactose and SNF yields for AS was a result of the higher milk yields for this group. Cows fed AS had significantly higher MUN levels $(P<0.01)$ than cows fed KRS. Because of the difference in dietary CP levels, it was not possible to determine whether the lower MUN concentrations on the KRS diet were due to improved N efficiency or were a reflection of the lower CP intake; however, it has been reported that protein breakdown in AS to NPN substantially reduces the efficiency of CP utilization by lactating dairy cows (Broderick, 1995).

\section{CONCLUSIONS}

The results of this study demonstrate that the KRS mixture ferments well and has the potential to be used as a silage crop for dairy cows. Although KRS had greater NDF concentration than AS, NDF digestibility of this mixture was also greater. Cows consuming the AS diet had higher DMI and 4\% FCM yields compared with cows consuming the KRS diet. However, cows similarly produced $1.5 \mathrm{~kg}$ of milk/kg of DMI consumed regardless of the diet, and milk composition was also similar for both groups. In addition to grazing this legume-grass mixture, the spring flush of forage could be harvested as high-quality silage for supplemental feed later in the grazing season or during the winter. It could also serve as an alternative forage in environments not suitable for consistent alfalfa production.

\section{ACKNOWLEDGMENTS}

The authors thank the farm crew for harvesting the forages and the barn crew for assistance in animal care and sampling at the University of Wisconsin-Madison Arlington Agricultural Research Station.

\section{REFERENCES}

Albrecht, K. A., and R. E. Muck. 1991. Proteolysis in ensiled forage legumes that vary in tannin concentration. Crop Sci. 31:464-469.

Allinson, D. W., G. S. Speer, R. W. Taylor, and K. Guillard. 1985. Nutritional characteristics of kura clover (Trifolium ambiguum Bieb.) compared with other forage legumes. J. Agric. Sci. 104:227-229.

AOAC. 2006. AOAC Official Methods of Analysis. 18th ed. Assoc. Off. Anal. Chem., Arlington, VA.

Balasko, J. A., and C. J. Nelson. 2003. Grasses for northern areas. Pages 125-143 in Forages: An Introduction to Grassland Agriculture. Vol. 1. 6th ed. R. F. Barnes, C. J. Nelson, M. Collins, and K. J. Moore, ed. Iowa State Univ. Press, Ames.

Broderick, G. A. 1995. Performance of lactating dairy cows fed either alfalfa silage or alfalfa hay as the sole forage. J. Dairy Sci. 78:320-329.

Brummer, E. C., and K. J. Moore. 2000. Persistence of perennial coolseason grass and legume cultivars under continuous grazing by beef cattle. Agron. J. 92:466-471.

Buxton, D. R. 1990. Cell-wall components in divergent germplasms of four perennial forage grass species. Crop Sci. 30:402-408.

Buxton, D. R., and G. C. Marten. 1989. Forage quality of plant parts of perennial grasses and relationship to phenology. Crop Sci. 29:429-435.

Buxton, D. R., D. R. Mertens, and D. S. Fisher. 1996. Forage quality and ruminant utilization. Pages 229-266 in Cool-Season Forage Grasses. L. E. Moser, D. R. Buxton, and M. D. Casler, ed. Am. Soc. Agron., Madison, WI.

Carlson, I. T., R. N. Oram, and J. Surprenant. 1996. Reed canarygrass and other Phalaris species. Pages 569-604 in Cool-Season Forage Grasses. L. E. Moser, D. R. Buxton, and M. D. Casler, ed. Am. Soc. Agron., Madison, WI.

Cherney, D. J. R., M. A. Alessi, and J. H. Cherney. 2006. Influence of grass species and sample preparation on ensiling characteristics. Crop Sci. 46:256-263.

Contreras-Govea, F. E., K. A. Albrecht, and R. E. Muck. 2006. Spring yield and silage characteristics of kura clover, winter wheat, and in mixtures. Agron. J. 98:781-787.

Dado, R. G., and M. S. Allen. 1996. Enhanced intake and production of cows offered ensiled alfalfa with higher neutral detergent fiber digestibility. J. Dairy Sci. 79:418-428.

Dewhurst, R. J., R. T. Evans, N. D. Scollan, J. M. Moorby, R. J. Merry, and R. J. Wilkins. 2003. Comparison of grass and legume silages for milk production. 2. In vivo and in sacco evaluations of rumen function. J. Dairy Sci. 86:2612-2621. 
Goering, H. K., and P. J. Van Soest. 1970. Forage Fiber Analyses (Apparatus, Reagents, Procedures, and Some Applications). Agric. Handbk. No. 379. Agric. Res. Serv., USDA, Washington, DC.

Kung, L., and R. Shaver. 2001. Interpretation and use of silage fermentation analysis reports. University of Wisconsin-Extension Publ. Series. Focus on Forage 3(13):1-5. http://www.uwex.edu/ ces/crops/uwforage/focusonforage.htm Accessed Nov. 1, 2007.

Lindgren, S. E., L. T. Axelsson, and R. F. McFeeters. 1990. Anaerobic L-lactate degradation by Lactobacillus plantarum. FEMS Microbiol. Lett. 66:209-214.

Marten, G. C., and A. W. Hovin. 1980. Harvest schedule, persistence, yield, and quality interactions among four perennial grasses. Agron. J. 72:378-387.

McKersie, B. D. 1985. Effect of $\mathrm{pH}$ on proteolysis in ensiled legume forage. Agron. J. 77:81-86.

Mertens, D. R. 1987. Predicting intake and digestibility using mathematical models of ruminal function. J. Anim. Sci. 64:1548-1558.

NRC. 2001. Nutrient Requirements of Dairy Cattle. 7th rev. ed. Natl. Acad. Press, Washington, DC.

Pederson, G. A. 1995. White clover and other perennial clovers. Pages 227-236 in Forages: An Introduction to Grassland Agriculture. Vol. 1. 5th ed. R. F. Barnes, D. A. Miller, and C. J. Nelson, ed. Iowa State Univ. Press, Ames.
SAS Institute. 1999. User's Guide: Statistics. Version 8 ed. SAS Inst., Cary, NC.

Seguin, P., and A. F. Mustafa. 2003. Chemical composition and ruminal nutrient degradabilities of fresh and ensiled kura clover (Trifolium ambiguum M. B.). Can. J. Anim. Sci. 83:577-582.

Sheaffer, C. C., and G. C. Marten. 1991. Kura clover forage yield, forage quality, and stand dynamics. Can. J. Plant Sci. 71:1169-1172.

Siegfried, V. R., H. Ruckemmann, and G. Stumpf. 1984. Method for the determination of organic acids in silage by high performance liquid chromatography. Landwirtsch. Forsch. 37:298.

Sleugh, B., K. J. Moore, J. R. George, and E. C. Brummer. 2000. Binary legume-grass mixtures improve forage yield, quality, and seasonal distribution. Agron. J. 92:24-29.

Smith, L. W., H. K. Goering, and C. H. Gordon. 1972. Relationships of forage compositions with rates of cell wall digestion and indigestibility of cell walls. J. Dairy Sci. 55:1140-1147.

Van Soest, P. J., J. B. Robertson, and B. A. Lewis. 1991. Methods for dietary fiber, neutral detergent fiber, and nonstarch polysaccharides in relation to animal nutrition. J. Dairy Sci. 74:35833597.

Zemenchik, R. A., K. A. Albrecht, and R. D. Shaver. 2002. Improved nutritive value of kura clover- and birdsfoot trefoil- grass mixtures compared with grass monocultures. Agron. J. 94:1131-1138. 